\title{
7,11,15,19-Tetramethyl-1,6,11,15,20,21-hexaaza-tricyclo[15.2.1.1 $\left.{ }^{6,9}\right]$ heneicosa- 7,9(21),17(20),18-tetraene
}

\author{
Rachid Touzani, abdelkrim Ramdani ${ }^{a}$ et Sghir El Kadiri ${ }^{\text {b* }}$ \\ ${ }^{a}$ Laboratoire de Chimie Organique-Physique \\ $\mathrm{b}^{*}$ Laboratoire de Chimie de l'Environnement et des Matériaux \\ Département de Chimie, Faculté Des Sciences, Université Mohamed Premier, \\ 60000 Oujda, Maroc \\ e-mail: elkadiri@sciences.univ-oujda.ac.ma
}

\section{Received: 27 June 2005 / Accepted: 10 August 2005 / Published: 1 November 2005}

Keywords: macrocyclic compounds, macrocyclic cavity, pyrazole

Despite the numerous polydentate macrocyclic structures already described as neutral receptors for various substrates [1-3], the search for new receptor families is still important with a view to obtaining molecules capable of molecular recognition, transport, selective catalysis, and biological models.

In this work, we are interested in the synthesis of mixed donor macrocycles incorporating $\mathrm{sp}^{3}$ and $\mathrm{sp}^{2}$ nitrogens. Some receptors of this type have been described to the cyclam family and are obtained from 2,6 disubstituted pyridines [4-5].

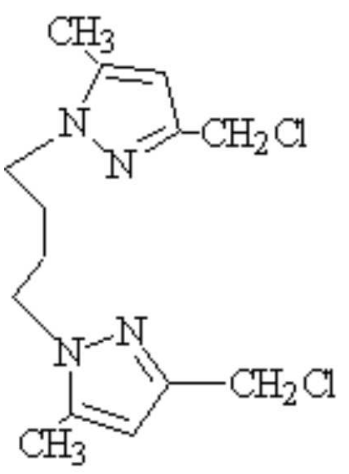

1

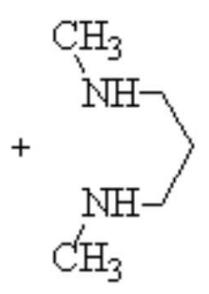

$\mathrm{Na}_{2} \mathrm{CO}_{3} / \mathrm{CH}_{3} \mathrm{CN}$

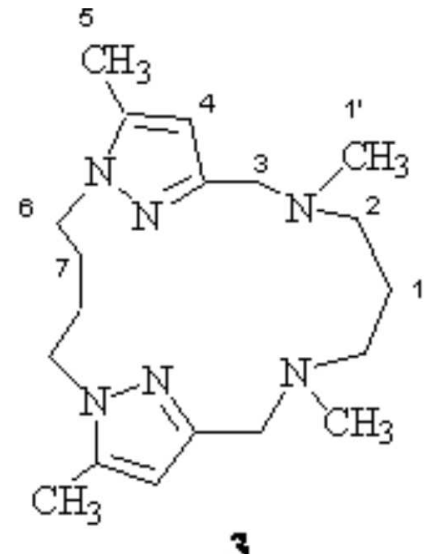

3

A suspension of sodium carbonate $(12 \mathrm{~g}, 120 \mathrm{mmol})$ in acetonitrile $(250 \mathrm{~mL})$ was refluxed under magnetic stirring, then a solution of 1,4-bis(3-chloromethyl-5-methylpyrazolyl)butane 1 (2.2 g, $7 \mathrm{mmol}$ ) [6], and $N, N^{\prime}$-dimethyl-propane-1,3-diamine $2(0.71 \mathrm{~g}, 7 \mathrm{mmol})$ in acetonitrile $(50 \mathrm{~mL})$ was added dropwise. The solution was refluxed under stirring for two hours, filtered and the solvent was removed in vacuum, the residue was purified on alumina column with $\left(\mathrm{CH}_{2} \mathrm{Cl}_{2} / \mathrm{MeOH}, 95 / 5\right)$ as eluant to give $1.7 \mathrm{~g}(70 \%)$ of macrocycle $\mathbf{3}$ as an oily substance.

${ }^{1} \mathrm{H}$ NMR $\left(250 \mathrm{MHz} ; \mathrm{CDCl}_{3}\right): \delta=5.90\left(\mathrm{~s}, 2 \mathrm{H}, \mathrm{H}^{4}\right) ; 4.00\left(\mathrm{t}, 4 \mathrm{H}, \mathrm{H}^{6}\right) ; 3.50\left(\mathrm{~s}, 4 \mathrm{H}, \mathrm{H}^{3}\right) ; 2.40\left(\mathrm{~s}, 6 \mathrm{H}, \mathrm{H}^{1^{\prime}}\right)$; $2.20\left(\mathrm{~d}, 6 \mathrm{H}, \mathrm{H}^{5}\right) ; 2.19\left(\mathrm{~m}, 4 \mathrm{H}, \mathrm{H}^{2}\right) ; 1.70\left(\mathrm{~m}, 4 \mathrm{H}, \mathrm{H}^{7}\right) ; 1.65\left(\mathrm{~m}, 2 \mathrm{H}, \mathrm{H}^{1}\right)$.

$\operatorname{MS}(\mathrm{FAB} ; \mathrm{m} / \mathrm{z}): 345[\mathrm{M}+\mathrm{H}]^{+}$

\section{References:}

1. Izatt R. M.; Christensen J. J. Progress in Macrocyclic Chemistry, Wiley-Interscience, New York, 1979, Vol. 1, 1981, Vol. 2.

2. Melson, G. A. Coordination Chemistry of Macrocycles, Plenum, New York, 1979. 
3. Bol, J. E.; Driessen, W. L. and Reedijk, J. J. Chem. Soc. Chem. Comm., 1995, 1365.

4. Lindoy L. F. The Chemistry of Macrocyclic Ligand Complexes, Cambridge University Press, Cambridge, 1988.

5. Hancok R. D.; Martell A. E ., Chem. Rev., 1989, 89, 1875

6. Tarrago, G.; El Kadiri, S.; Marzin, C. and Coquelet, C. New. J. Chem., 1991, 15, 677.

Sample Availability: Available from MDPI.

(C) 2005 MDPI. All rights reserved. 